\title{
PENGEMBANGAN BAHAN AJAR BERBASIS KONSTRUKTIVIS PADA MATA KULIAH TELAAH KURIKULUM FISIKA II (TKF II) UNTUK MAHASISWA KELAS INTERNASIONAL DI JURUSAN FISIKA UNESA
}

\author{
Supriyono \\ Jurusan Fisika Universitas Negeri Surabaya
}

\begin{abstract}
Abatrak
Perkuliahan Telaah Kurikulum Fisika di Jurusan Fisika dilaksanakan setiap semester dengan cakupan untuk semester gasal membahas konsep-konsep fisika untuk tingkat SMP dan untuk semester genap membahas konsep-konsep fisika SMA. Peran mata kuliah ini sangat penting karena untuk lebih menguatkan konsep-konsep dasar yang diperoleh mahasiswa dalam perkuliahan Fisika Dasar. Berdasarkan hasil pengamatan terhadap pelaksanaan kegiatan perkuliahan , ada beberapa fakta yang dapat disampaikan, antara lain: Mahasiswa masih kesulitan bernalar tentang konsep untuk menjelaskan fenomena dalam kehidupan sehari-hari. Standar ini masih cukup jauh dari kompetensi yang ingin dicapai pada mata kuliah ini yaitu mahasiswa mampu menganalisis cakupan materi dalam kurikulum SMA,menentukan kedalaman materi, menguasai konsep-konsep dan dapat menggunakan konsep-konsep tersebut untuk menyelesaikan masalah kehidupan sehari-hari.Dengan demikian sangat diperlukan buku ajar yang dapat digunakan sebagai rujukan dalam memahami konsep-konsep dasar fisika sesuai kebutuhan calon guru di tingkat Sekolah Menengah. Tujuan utama dalam penelitian ini adalah dihasilkan buku ajar untuk mata kuliah Telaah Kurikulum Fisika II (TKF II) yang layak digunakan di Kelas Internasional ditinjau dari kesesuaian buku tersebut dalam mengembangkan kompetensi mahasiswa di kelas internasional Jurusan Fisika. Tujuan yang lain yang ingin dicapai melalui penelitian ini adalah (a) Mendiskripsikan kelayakan bahan ajar yang dikembangkan dengan pencapaian kompetennsi pada mata kuliah TKF II untuk mahasiswa Kelas Internasional. (b) Mendiskripsikan keterampilan mahasiswa Kelas Internasional dalam menganalisis konsep berdasarkan SK dan KD pada Kurikulum Fisika SMA? (c)Mendiskripsikan respon mahasiswa Kelas Internasional terhadap bahan ajar berbasis konstruktivis yang dikembangkan. Metode pengembangan bahan ajar ini mengacu pada kerangka pikir Thiagarajan dan Semmel \&Semmel yang terdiri dari empat tahap yaitu: tahap define (penetapan), design (perancangan), develop (pengembangan), dan dessiminate (penyebaran). Tahap define dan design masuk pada fase perencanaan pengembangan sedangkan develop dan dessiminate masuk dalam fase pengembangan. Kesimpulan dari hasilpenelitian ini adalah: (a) Buku ajar berbasis konstruktivis untuk mata kuliah TKF II cukup baik dan layak digunakan, (b) Ditinjau dari kelayakan isi, kebahasaan, sajian dan kegrafisan sudah cukup baik walaupun masih perlu disempurnakan (c) Keterampilan mahasiswa dalam menganalisis konsep relatif masih rendah dan perlu ditingkatkan. (d) Respon mahasiswa terhadap bahan ajar yang dikembangkan cukup baik.
\end{abstract}

Kata Kunci: bahan ajar, konstruktivis, TKF II. 


\section{PENDAHULUAN}

Pemahaman konsep yang baik sangat diperlukan bagi guru dalam memberikan layanan pembelajaran yang bermutu bagi para siswa, sehingga dalam setiap materi perkuliahan khususnya bagi mahasiswa pendidikan Fisika harus diorientasikan pada bagaimana memahami konsep dan bagaimana membelajarkannya.

Kondisi ini menjadi salah satu permasalahan bagi para mahasiswa Pendidikan Fisika di Jurusan Fisika khususnya untuk kelas internasional. Berdasarkan hasil pengukuran pemahaman konsep melalui tes kemampuan kognitif terkait dengan konsep-konsep dasar dalam materi fisika pada mata kuliah Telaah Kurikulum Fisika I (Analysis of Physics Curriculum I) untuk kelas Internasional rata-rata menunjukkan hasil yang kurang maksimal. $15 \%$ mahasiswa mendapatkan nilai lebih dari 85, $65 \%$ mendapatkan nilai dengan rentang70-85 dan $20 \%$ mendapatkan nilai <60.Karakteristik soal yang sulit dikerjakan oleh mahasiswa adalah yang terkait dengan pemahaman konsep dan aplikasi konsep.Secara teori, mahasiswa memiliki pengetahuan yang baik tentang konsep-konsep fisika, namun pada saat dihadapkan pada pengaplikasian konsep terkait dengan masalah-masalah fisika, mahasiswa sering mengalami kesulitan.

Mahasiswa masih kesulitan bernalar tentang konsep untuk menjelaskan fenomena dalam kehidupan sehari-hari. Standar ini masih cukup jauh dari kompetensi yang ingin dicapai pada mata kuliah ini yaitu mahasiswa mampu menganalisis cakupan materi dalam kurikulum SMA,menentukan kedalaman materi, menguasai konsep-konsep dan dapat menggunakan konsep-konsep tersebut untuk menyelesaikan masalah kehidupan seharihari (Kurikulum Pendidikan Fisika 2008).

Konsep menjadi bagian penting dalam mempelajari materi.Dalam mempelajari dan menerapkan konsep diperlukan kecakapan khusus bagi mahasiswa.Penerapan konsep memerlukan kemampuan untuk menganalisis obyek dan fenomena untuk menerapkan konsep tersebut (Darliana, 2007). Dalam pembelajaran mata kuliah Telaah Kurikulum Fisika I dan II(Analysis of Physics Curriculum I and II)khususnya bagi mahasiswa kelas internasional, konsep menjadi perhatian dalam setiap kegiatan pembelajaran karena tingginya kompetensi yang harus dimiliki oleh mahasiswa kelas internasioanl.

Untuk mendapatkan hasil yang maksimal, mahasiswa diberikan kesempatan untuk mengkomunikasikan ide-ide yang terkait dengan konsep. Mahasiswa membuat makalah sesuai dengan konsep pada satuan pendidikan yang disepakati kemudian dipresentasikan di depan kelas. Ada beberapa keuntungan yang diperoleh dari strategi perkuliahan ini yaitu: mahasiswa lebih aktif dalam mengkaji dan mengkomunikasikan konsep dan lebih berani mengemukakan pendapat namun terkait dengan pemahaman konsep dinilai masih kurang.

Perkuliahan Telaah Kurikulum di Jurusan Fisika dilaksanakan setiap semester dengan cakupan untuk semester gasal membahas konsep-konsep fisika untuk tingkat SMP dan untuk semester genap membahas konsep-konsep fisika SMA.Peran mata kuliah ini sangat penting karena untuk lebih menguatkan konsepkonsep dasar yang diperoleh mahasiswa dalam perkuliahan Fisika Dasar.Berdasarkan hasil pengamatan terhadap pelaksanaan kegiatan perkuliahan , ada beberapa fakta yang dapat disampaikan, antara lain:

1. Telah terjadi miskonsepsi yang fatal pada mahasiswa sehingga komunikasi tentang konsep tetap berdasarkan pada pemahaman yang salah terhadap konsep tersebut.

2. Mahasiswa kurang terampil memilih sumber belajar yang benar sesuai dengan konsep yang dipelajari sehingga menambah permasalahan terhadap penguasaan konsep. 
Dalam mengatasi masalah tersebut, diperlukan sebuah kinerja yang sistematis bagi para dosen pengampu mata kuliah sehingga masalah-masalah yang terkait dengan penguasaan konsep dapat diselesaikan dengan baik.Pembelajaran yang direncanakan harus terkait dengan upaya menanamkan konsep bagi mahasiswa sekaligus membimbing mahasiswa untuk bisa menerapkan konsep-konsep tersebut dengan baik utamanya untuk menyelesaikan masalah-masalah dalam kehidupan seharihari.

\subsection{Rumusan Masalah}

Berdasarkan paparan di atas, permasalahan utama terkait dengan penelitian pengembangan ini adalah "Bagaimanakah Kualitas Bahan Ajar Berbasis Konstruktivis untuk Mata Kuliah Telaah Kurikum Fisika II (Analysis of Physics Curriculum II)) MahasiswaKelas Internasional di Jurusan Fisika Unesa?". Dari masalah utama tersebut terdapat beberapa sub masalah yang akan dijawab melalui penelitian ini, antara lain:

a. Bagaimanakah kelayakan bahan ajarberbasis konstruktivis yang dikembangkan dengan pencapaian kompetensi pada mata kuliah Telaah Kurikulum Fisika II (Analysis of Physics Curriculum II)) untuk mahasiswa Kelas Internasional?

b. Bagaimanakah keterampilan mahasiswa Kelas Internasional dalam menganalisis konsep dari SK dan KD Kurikulum Fisika SMA?

c. Bagaimanakah respon mahasiswa Kelas Internasional terhadap bahan ajar berbasis konstruktivis yang dikembangkan?

\subsection{Tujuan Penelitian}

Tujuan utama dalam penelitian ini adalah dihasilkan buku ajar untuk mata kuliah Telaah Kurikulum Fisika II (Analysis of Physics Curriculum II) yang layak digunakan di Kelas Internasional ditinjau dari kesesuaian buku tersebut dalam mengembangkan kompetensi mahasiswa di kelas internasional Jurusan Fisika.
Tujuan yang lain yang ingin dicapai melalui penelitian ini adalah:

a. Mendiskripsikan kelayakan bahan ajar yang dikembangkan dengan pencapaian kompetennsi pada mata kuliah Telaah Kurikulum Fisika II (Analysis of Physics Curriculum II) untuk mahasiswa Kelas Internasional.

b. Mendiskripsikan keterampilan mahasiswa Kelas Internasional dalam menganalisis konsep berdasarkan SK dan KD pada Kurikulum Fisika SMA?

c. Mendiskripsikan respon mahasiswa Kelas Internasional terhadap bahan ajar berbasis konstruktivia yang dikembangkan.

\subsection{Manfaat Penelitian}

Beberapa manfaat dari penelitian ini adalah:

a. Bagi Lembaga

- Tersedianya bahan ajar yang sesuai dengan kebutuhan mahasiswa yang dapat digunakan dalam perkuliahan Telaah Kurikulum Fisika II (Analysis of Physics Curriculum II) di Jurusan Fisika UNESA.

- Menjadi model alternatif dalam men ingkatkan mutu perkuliahan Telaah Kurikulum Fisika II (Analysis of Physics Curriculum II) di Jurusan Fisika.

- Meningkatkan budaya dan minat meneliti bagi para dosen di Jurusan Fisika UNESA.

b. Bagi Peneliti

- Pengembangan keilmuan bagi peneliti.

- Bentuk pengabdian pada tridarma perguruan tinggi melalui kegiatan penelitian.

- Memiliki hasil penelitian yang dapat dimanfaatkan oleh masyarakat luas.

\section{METODE PENELITIAN}

\subsection{Desain Penelitian}

Untuk dapat menghasilkan bahan ajar yang inovatif, langkah-langkahnya dapat dilihat pada diagram alir berikut: 


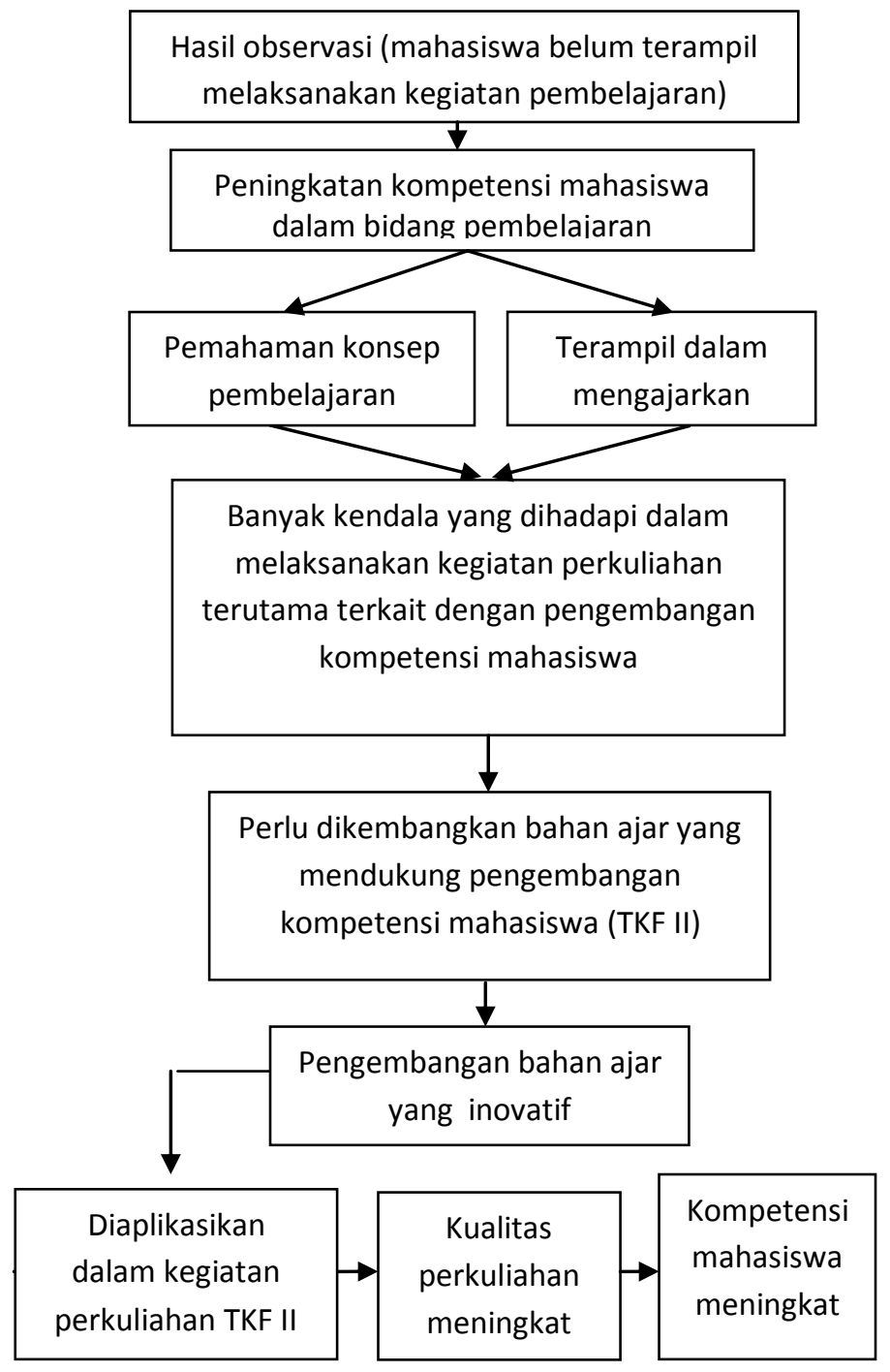

Gambar 1. Kerangka Pengembangan

\subsection{Data-data yang diperlukan}

Dalam penelitian ini, data-data yang diperlukan dalam kegiatan penelitian pengembangan bahan ajar untuk mata kuliah Analysis of Physics Curriculum II antara lain:

1. Hasil penilaian kelayakan buku ajar

Penilaian kelayakan buku ajar didasarkan pada kemampuan buku tersebut memfasilitasi mahasiswa dalam menggali konsep-konsep fisika selain juga memperhatikan kelengkapan buku tersebut. Penilaian kelayakan buku ajar dinilai berdasarkan komponen-komponen sebagai berikut: (a) Kelayakan isi, (b)
Kebahasaan, (c) sajian, dan (d) kegrafisan.

2. Keterampilan mahasiswa dalam menganalisis konsep berdasarkan SK dan KD

Keterampilan mahasiswa dalam menganalisis konsep dari SK dan KD dapat diukur dari (a) mengidentifikasi konsep yang perlu diajarkan, (b) membedakan konsep, prinsip, hukum dan teori, (c) melakukan pengecekan konsep dari buku sumber/penunjang/materi yang digunakan, (d) mengidentifikasi tingkat kesulitan konsep, (e) mengidentifikasi contoh yang dapat membantu menjelaskan konsep, (f) mengidentifikasi apakah konsep tersebut perlu ditunjang 
dalam kegiatan berbasis laboratorium atau tidak, dan (g) merancang cara penyampaian kosep.

3. Respon mahasiswa

Respon mahasiswa adalah tanggapan mahasiswa terhadap isi buku ajar yang digunakan dalam kegiatan perkuliahan Analysis of Physics Curriculum II.

\subsection{Instrumen yang digunakan}

Beberapa instrument yang digunakan dalam penelitian sesuai dengan variabel yang diteliti antara lain:

a. Lembar penilaian kelayakan buku ajar.

b. Lembar penilaian keterampilan menganalisis konsep

c. Angket respon mahasiswa

\subsection{Teknik Pengolahan Data}

Data yang diperoleh dalam penelitian adalah deskripsi tentang buku ajar yang berhasil disusun dan dikembangkan.Sesuai dengan jenis penelitian, yaitu deskriptip kualitatif, data yang diperoleh dari instrument penelitian disajikan secara table dan grafis kemudian di deskripsikan untuk mendapatkan jawaban dari permasalahanpermasalahan yang telah dirumuskan.

\section{HASIL DAN PEMBAHASAN}

\subsection{Hasil Penelitian}

a. Buku Ajar yang dikembangkan

Buku ajar yang dikembangkan dalam penelitian ini adalah buku ajar untuk mata kuliah Analysis of Physics Curriculum II.Hasil penilaian terhadap buku ajar yang dilakukan oleh mahasiswa kelas internasional angkatan 2010 yang dianggap cakap dan mampu memberikan penilaian terhadap buku ajar yang dikembangkan. Hasil penilaian dapat disajikan dalam tabel berikut:

Tabel 1. Hasil Penilaian Buku Ajar

\begin{tabular}{|c|c|c|c|c|c|c|}
\hline \multirow{2}{*}{ No } & \multirow{2}{*}{ Komponen } & \multicolumn{5}{|c|}{ Prosentase skor } \\
\hline & & 1 & 2 & 3 & 4 & 5 \\
\hline & KELAYAKAN ISI & & & & & \\
\hline 1. & $\begin{array}{l}\text { Kesesuaian dengan } \\
\text { SK dan KD pada } \\
\text { kurikulum SMA }\end{array}$ & & & 9.09 & 54.55 & 36.36 \\
\hline 2. & $\begin{array}{l}\text { Kesesuaian dengan } \\
\text { kebutuhan mahasiswa }\end{array}$ & & & 36.36 & 54.55 & 9.09 \\
\hline 3. & $\begin{array}{l}\text { Mendorong } \\
\text { mahasiswa untuk } \\
\text { dapat menemukan } \\
\text { konsep secara sendiri }\end{array}$ & & & 36.36 & 45.45 & 18.18 \\
\hline 4. & $\begin{array}{l}\text { Kebenaran substansi } \\
\text { materi }\end{array}$ & & & 45.45 & 63.64 & 27.27 \\
\hline 5. & $\begin{array}{l}\text { Manfaat untuk } \\
\text { meningkatkan } \\
\text { pemahaman konsep. }\end{array}$ & & & 27.27 & 54.55 & \\
\hline 6. & $\begin{array}{l}\text { Kesesuaian dengan } \\
\text { nilai-nilai, moralitas, } \\
\text { social }\end{array}$ & & 9.09 & 27.27 & 63.64 & \\
\hline & Rata-rata & & 9.09 & 30.30 & 56.06 & 22.73 \\
\hline & KEBAHASAAN & & & & & \\
\hline 7. & Keterbacaan & & 9.09 & 27.27 & 54.55 & 9.09 \\
\hline 8. & Kejelasan informasi & & & 27.27 & 72.73 & \\
\hline 9. & $\begin{array}{l}\text { Kesesuaian dengan } \\
\text { kaidah bahasa yang } \\
\text { digunakan }\end{array}$ & & 18.18 & & 72.73 & 9.09 \\
\hline
\end{tabular}




\begin{tabular}{|c|c|c|c|c|c|c|}
\hline \multirow{2}{*}{ No } & \multirow{2}{*}{ Komponen } & \multicolumn{5}{|c|}{ Prosentase skor } \\
\hline & & 1 & 2 & 3 & 4 & 5 \\
\hline \multirow[t]{3}{*}{10.} & $\begin{array}{l}\text { Penggunaan bahasa } \\
\text { secara efektif dan } \\
\text { efisien }\end{array}$ & & & 36.36 & 45.45 & 18.18 \\
\hline & Rata-rata & & 13.64 & 30.30 & 62.11 & 12.12 \\
\hline & SAJIAN & & & & & \\
\hline 11. & Kejelasan tujuan & & 9.09 & 27.27 & 54.55 & 9.09 \\
\hline 12. & Urutan penyajian & & & 18.18 & 90.91 & \\
\hline 13. & Pemberian motivasi & & 9.09 & 90.91 & & \\
\hline 14. & $\begin{array}{l}\text { Interaktivitas } \\
\text { (stimulus dan respon) }\end{array}$ & & & 54.55 & 27.27 & 9.09 \\
\hline \multirow[t]{3}{*}{15.} & $\begin{array}{l}\text { Kelengkapan } \\
\text { informasi }\end{array}$ & & & 45.45 & 36.36 & 9.09 \\
\hline & Rata-rata & & 9.09 & 47.27 & 52.27 & 9.09 \\
\hline & KEGRAFISAN & & & & & \\
\hline 16. & $\begin{array}{l}\text { Penggunaan font } \\
\text { (jenis dan ukuran) }\end{array}$ & & & 45.45 & 54.54 & \\
\hline 17. & Lay out, tata letak & & & 36.36 & 63.64 & \\
\hline 18. & $\begin{array}{l}\text { Ilustrasi, grafis, } \\
\text { gambar, foto }\end{array}$ & & & 36.36 & 63.64 & \\
\hline 19. & Desain tampilan & & & 36.36 & 63.64 & \\
\hline & Rata-rata & & & 38.63 & 61.19 & \\
\hline
\end{tabular}

Berdasarkan data di atas, dapat dijelaskan kelayakan buku hasil penilaian responden.9.09\% menilai buku kurang layak, $30.30 \%$ reponden menyatakan isi buku cukup layak, $56.06 \%$ menyatakan layak, dan $22.73 \%$ menyatakan sangat layak. Dari segi kebahasaan, $13.64 \%$ responden menyatakan kurang sesuai/kurang layak, $30.30 \%$ menyatakan cukup layak, $62.11 \%$ menyatakan layak dan $12.12 \%$ menyatakan sangat layak. Untuk aspek sajian $9.09 \%$ responden menyatakan kurang layak, $42.27 \%$ menyatakan cukup layak, $52.27 \%$ menyatakan layak dan 9.09 $\%$ menyatakan sangat layak. Tentang kegrafisan, $38.63 \%$ cukup layak, $61.19 \%$ menyatakan layak. Berdasarkan hasil penilaian terhadap penilaian kelayakan buku ajar berbasis konstruktivis yang dikembangkan dapat digrafikan sebagai berikut:

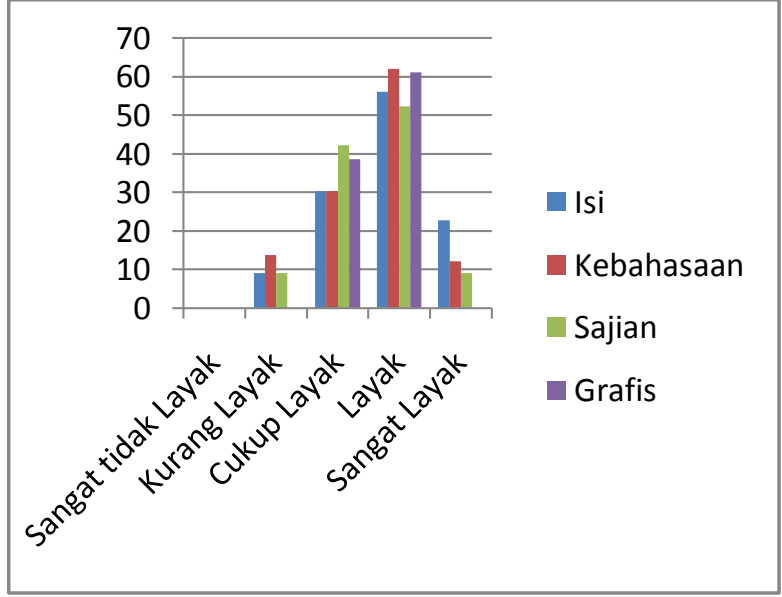

Gambar 1. .Grafik Penilaian Kelayakan Buku Ajar

Berdasarkan grafik diatas, buku ajar yang dikembangkan dinilai layak digunakan.Namun ada beberapa catatan dari mahasiswa terkait dengan buku ajar tersebut. 
Tabel 2. Catatan terhadap buku ajar

\begin{tabular}{|c|c|c|}
\hline No & Aspek yang dinilai & Catatan \\
\hline 1. & Kelayakan isi & $\begin{array}{l}\text { - } \text { Kesesuaian indicator/tujuan dengan materi kurang. } \\
\text { - } \quad \text { Asesmen harus memperhatikan kesesuaian dengan materi dan dilengkapi } \\
\text { dengan jawaban. } \\
\text { - } \text { Mini lab tidak sesuai dengan indicator } \\
\text { - } \text { Kurang dilengkapi dengan referensi } \\
\text { - } \\
\text { - }\end{array}$ \\
\hline 2. & Kebahasaan & - Masih terdapat penggunaan Bahasa Indonesia \\
\hline 3. & Sajian & $\begin{array}{l}\text { - } \quad \text { Ditambahkan fenomena baru yang lebih menarik dan memberi motivasi. } \\
\text { - } \quad \text { Penjelasan pada materi kurang menarik. } \\
\text { - } \quad \text { Penggunaan spasi kurang diperhatikan. }\end{array}$ \\
\hline 4. & Kegrafisan & $\begin{array}{l}\text { - Ada ilustrasi gambar pada fenomena yang disampaikan. } \\
\text { - Perlu ada pembenahan dalam penggunaan font agar seragam } \\
\text { - Untuk gambar yang seharusnya berwarna ditampilkan sesuai dengan } \\
\text { warna sebenarnya. }\end{array}$ \\
\hline
\end{tabular}

Dari catatan di atas, poin penting yang perlu diperhatikan dalam buku ajar Analysis Physics of Curriculum II adalah dilakukan penyempurnaan terhadap kelayakan isi, kebahaasaan, sajian maupun kegrafisan.

\subsection{Keterampilan Mahasiswa dalam \\ Menganalisis Konsep}

Bagian penting dalam mata kuliah Analysis Physics of Curriculum II adalah keterampilan mahasiswa dalam menganalisis konsep berdasarkan SK dan KD dalam kurikulum SMA. Beberapa indicator yang digunakan untuk menilai keterampilan mahasiswa dalam menganalisis konsep antara lain: (a) mengidentifikasi konsep yang perlu diajarkan, (b) membedakan konsep, prinsip, hukum dan teori, (c) melakukan pengecekan konsep dari buku sumber/penunjang/materi yang digunakan, (d) mengidentifikasi tingkat kesulitan konsep, (e) mengidentifikasi contoh yang dapat membantu menjelaskan konsep, (f) mengidentifikasi apakah konsep tersebut perlu ditunjang dalam kegiatan berbasis laboratorium atau tidak, dan (g) merancang cara penyampaian kosep.

Tabel 3 Hasil penilaian keterampilan menganalisis konsep

\begin{tabular}{|c|c|c|c|c|}
\hline \multirow{2}{*}{ No. } & \multirow{2}{*}{ Aspek yang dinilai } & \multicolumn{3}{|c|}{ Kategori (\%) } \\
\hline & & Baik & Cukup & Kurang \\
\hline 1. & $\begin{array}{l}\text { Mengidentifikasi konsep yang perlu diajarkan } \\
\text { sesuai dengan SK dan KD pada kurikulum } \\
\text { Fisika SMA }\end{array}$ & 18.75 & 56.25 & 25.00 \\
\hline 2. & Membedakan konsep, prinsip, hukum dan teori & 37.50 & 31.25 & 31.25 \\
\hline 3. & Mengidentifikasi tingkat kesulitan konsep & 43.75 & 25.00 & 31.25 \\
\hline 4. & $\begin{array}{l}\text { Mengidentifikasi contoh yang dapat membantu } \\
\text { menjelaskan konsep }\end{array}$ & 31.25 & 56.25 & 12.50 \\
\hline 5. & $\begin{array}{l}\text { Mengidentifikasi apakah konsep tersebut perlu } \\
\text { ditunjang dalam kegiatan berbasis } \\
\text { laboratorium atau tidak }\end{array}$ & 18.75 & 37.50 & 43.75 \\
\hline 6. & merancang cara penyampaian konsep & 37.50 & 18.75 & 43.75 \\
\hline & Rata-rata & 31.25 & 37.50 & 31.25 \\
\hline
\end{tabular}


Berdasarkan tabel data di atas, keterampilan mahasiswa dalam menganalisis konsep sesuai dengan SK dan KD pada kurikulum Fisika SMA ratarata masih rendah $(<50 \%)$.Dari 16 mahasiswa, hanya $31.25 \%$ dinyatakan memiliki keterampilan baik dalam menganalisis konsep, $37.50 \%$ dinyatakan cukup, dan $31.25 \%$ dinyatakan kurang.
Secara diagram dapat disajikan sebagai berikut:

\subsection{Respon Mahasiswa}

Untuk mengetahui respon mahasiswa terhadap pembelajaran yang dilaksanakan dengan menggunakan buku yang sudah dikembangkan dapat disajikan pada tabel berikut:

Tabel 4. Data Respon Mahasiswa

\begin{tabular}{|c|c|c|c|c|c|c|}
\hline \multirow{2}{*}{ No } & \multirow{2}{*}{ Pernyataan sikap } & \multicolumn{5}{|c|}{ Penilaian } \\
\hline & & $\mathbf{A}$ & B & $\mathbf{C}$ & D & $\mathbf{E}$ \\
\hline 1. & $\begin{array}{l}\text { Apa yang saya pelajari dalam buku ini berguna } \\
\text { bagi saya. }\end{array}$ & & & & 33 & 67 \\
\hline 2. & $\begin{array}{l}\text { Saya yakin dapat mengikuti pelajaran ini dengan } \\
\text { baik. }\end{array}$ & & & & 100 & \\
\hline 3. & Pembelajaran ini kurang menarik perhatian saya. & 9 & 58 & 25 & 8 & \\
\hline 4. & Dosen membuat materi pelajaran tampak penting. & & & 25 & 50 & 25 \\
\hline 5. & $\begin{array}{l}\text { Saya merasa beruntung memperoleh nilai yang } \\
\text { baik dalam pembelajaran ini. }\end{array}$ & & & 16 & 50 & 34 \\
\hline 6. & Saya merasa puas mengikuti pelajaran ini. & & 8 & 33 & 50 & 9 \\
\hline 7. & Saya senang mengikuti pembelajaran ini. & & & 8 & 92 & \\
\hline 8. & $\begin{array}{l}\text { Isi pembelajaran ini sesuai dengan harapan dan } \\
\text { tujuan saya. }\end{array}$ & & 8 & 25 & 50 & 17 \\
\hline 9. & $\begin{array}{l}\text { Keuntungan pribadi dalam kegiatan pembelajaran } \\
\text { ini cukup jelas bagi saya. }\end{array}$ & & & 25 & 41 & 34 \\
\hline 10. & $\begin{array}{l}\text { Pertanyaan-pertanyaan yang diajukan atau } \\
\text { masalah-masalah yang diberikan pada } \\
\text { pembelajaran ini mendorong rasa ingin tahu saya. }\end{array}$ & & & 8 & 75 & 17 \\
\hline
\end{tabular}

Keterangan:

A: Sangat tidak setuju, B: Tidak Setuju, C:Kurang setuju, D. Srtuju, E. Setuju sekali

Berdasarkan data di atas sesuai dengan respon mahasiswa yang melaksanakan proses pembelajaran dengan menggunakan buku yang sudah dikembangkan oleh peneliti dapat diinformasikan bahwa mahasiswa memiliki respon yang baik terhadap pembelajaran yang dilaksanakan oleh dosen. $58.33 \%$ mahasiswa sangat setuju bahwa pelajaran yang diterima berguna bagi mahasiswa.Pada pernyataan yang menyatakan saya yakin dapat mengikuti pelajaran dengan baik 100 $\%$ mahasiswa setuju.

Sikap tertarik pada pelajaran dapat dilihat dari pernyataan ketiga. 58.33\% mahasiswa tidak setuju jika pelajaran ini kurang menarik dan $8.33 \%$ sangat tidak setuju jika pelajaran ini kurang menarik. Artinya lebih dari 50\% mahasiswa tertarik dengan pelajaran yang dilaksanakan oleh dosen.Hal ini bisa disebabkan mahasiswa terbiasa berlaku pasif dalam pembelajaran.

Hal menarik dari KBM yang dilakukan oleh dosen, pembelajaran disajikan sehingga pelajaran tampak penting, hal ini sesuai dengan angket mahasiswa yang menyatakan setuju 50,0\%. Sedangkan kesesuaian dengan tujuan cukup baik karena $68,0 \%$ setuju bahwa materi pelajaran sesusai dengan harapan dan tujuan mahasiswa bahkan 33.33 $\%$ mahasiswa sangat setuju bahwa materi ini sesuai dengan harapan. 
Dari hasil penelitian diatas, dapat disimpulkan bahwa kegiatan pembelajaran yang dlaksanakan dapat mengoptimalkan respon mahasiswa untuk dapat belajar secara baik walaupun masih ada respon mahasiswa yang kurang baik namun dengan penyempurnaan kegiatan pembelajaran akan dapat meningkatkan respon mahasiswa.

\subsection{Pembahasan}

Dalam meningkatkan kualitas perkuliahan sangat diperlukan bahan ajar yang representatif. Sesuai dengan karakteristik mata kuliah Analysisis Curriculum of Physics II yang lebih mengutamakan pada penguasaan konsep Fisika sesuai dengan SK dan KD pada kurikulum Fisika SMA sangat diperlukan buku ajar yang mampu membantu mahasiswa dalam menggali dan menemukan konsep secara mandiri. Sesuai dengan tujuan penelitian dalam kegiatan ini adalah dikembangkan buku ajar untuk mata kuliah Analysisis Curriculum of Physics II berbasis konstruktivis.

Buku ajar ini diharapkan dapat memenuhi kebutuhan belajar mahasiswa kelas internasional di Jurusan Fisika yang memiliki tuntutan kompetensi lebih dibandingkan dengan mahasiswa lainnya.Pembelajaran dalam kelas internasional hendaknya didukung dengan buku ajar yang berkualitas untuk semua mata kuliah dan dosen-dosen atau staf pengajar yang memiliki pengalaman dan kemampuan/skills dibidangnya, selain itu dia juga sangat konsen dengan bidang dia tersebut, karena nantinya lulusan dari kelas ini diharapkan memiliki kualitas dalam bidangnya, sehingga dosen dalam memberikan pembelajaran juga harus sesuai dengan tujuan akhir yang akan diraih. kemampuan fisik maupun psikis juga harus dimiliki oleh para dosen kelas internasional ini, karena tidak menutup kemungkinan apabila jejaring yang telah dibuat oleh Universitas untuk kelas internasionalnya ini luas maka para staf pengajar juga akan memberikan perkuliahan ke luar negeri.
Hasil pengembangan buku ajar untuk mata kuliah Analysisis Curriculum of Physics II menunjukkan hasil bahwa buku ajar berbasis konstruktivis ini layak digunakan untuk kegiatan pembelajaran di kelas Internasional. Melalui buku ajar ini akan lebih mampu membantu mahasiswa untuk dapat memahami konsep-konsep fisika pada tingkat satuan pendidikan SMA.

Hasil identifikasi yang menarik dikemukakan dalam penelitian ini adalah keterampilan mahasiswa dalam menganalisis konsep fisika, ternyata ratarata masih rendah.Hal ini mengindikasikan pembelajaran yang dilaksanakan terkait dengan penguasaan konsep belum mampu mengkontruk pemahaman konsep mahasiswa dengan baik.

\section{SIMPULAN DAN SARAN}

\subsection{Simpulan}

Beradasarkan hasil penelitian dan pembahasan, dapat dirumuskan kesimpulan sebagai berikut:

a. Buku ajar berbasis konstruktivis untuk mata kuliah Analysisis Curriculum of Physics II cukup baik dan layak digunakan. Ditinjau dari kelayakan isi, kebahasaan, sajian dan kegrafisan sudah cukup baik walaupun masih perlu disempurnakan.

b. Keterampilan mahasiswa dalam menganalisis konsep relatif masih rendah dan perlu ditingkatkan.

c. Respon mahasiswa terhadap bahan ajar yang dikembangkan cukup baik.

\subsection{Saran}

Beberapa saran yang perlu disampaikan dalam penelitian antara lain:

a. Buku ajar yang dikembangkan perlu untuk dikaji secara terus menerus menyesuaikan dengan perkembangan pembelajaran di lapangan.

b. Perlu dikembangkan buku ajar untuk materi yang lain. 
DAFTAR PUSTAKA

Abbeduto, Leonard, (2004) Taking Sides: Clashing Views on Controversial Issues in Educational Psychology, Third Edition, McGraw-Hill/Dushkin.

Darliana, (2007).Keterampilan Berpikir Kompleks dan implementasinya dalam Pembelajaran Fisika. Jakarta: Puspendik dan Tenaga Kependidikan IPA

Depdiknas, 2009, Panduan Pengembangan Bahan Ajar. Jakarta

Hidayat, A. 2009.Pengembangan CDROM Interaktif Sebagai Bahan Ajar Praktik Akuntansi

II. http:educare.e- fkipunia.net. diakses pada tanggal 16 September 2009.

Kemp, J.E., Morrison, G.R., \& Ross, S.M. (1996).Designing Effective Instruction, 2nd Edition. Upper Saddle River, NJ: Prentice-Hall.

Nur, M, 2000, Buku panduan Keterampilan Proses dan Hakikat Sains: Surabaya

Thiagarajan, S., semmel, D.s., \& Semmel, M.I. 1974.Instructional Development for Training Teachers of Exceptional Children. Minneapolish, Minnesota: Leadership Training Institute/Special Education, University of Minnesota. 